\title{
JTE
}

Journal of Teachers of English

Volume 5 No. 1

e-ISSN: $2548-6810$

\section{THE EFFECT OF NURSERY RHYMES ON STUDENTS' VOCABULARY ACHIEVEMENT AT THE FIFTH GRADE OF SDN 10 POASIA}

\author{
Ella Angriana', Lelly Suhartini ${ }^{2}$, Sitti Agustina ${ }^{3}$
}

1,2,3 Halu Oleo University, Indonesia.

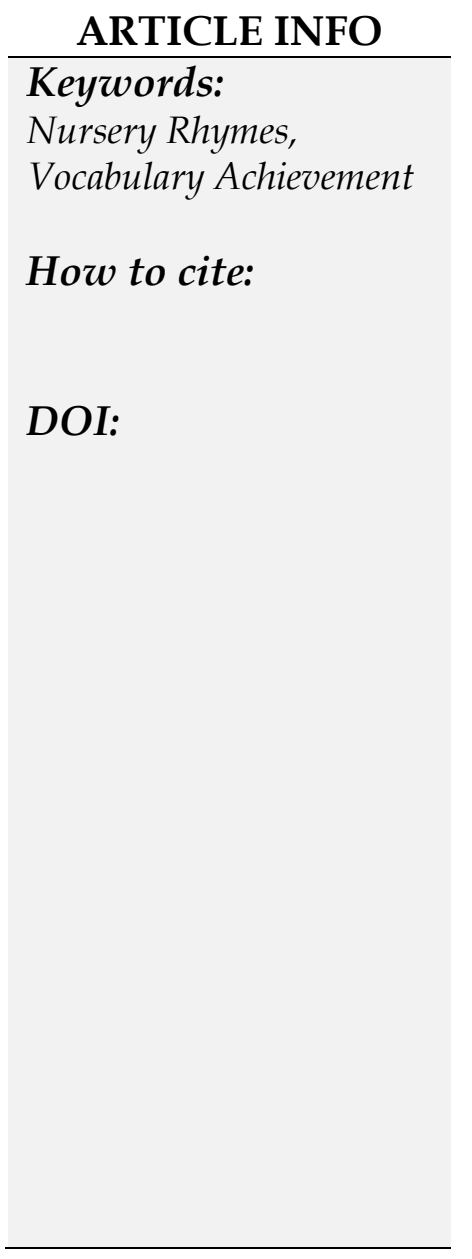

\begin{abstract}
This study is conducted to investigate the effect of using nursery rhymes on students' English vocabulary (noun and adjective) achievement at fifth grade of SDN 10 Poasia. This study applied pre-experimental design with one group pre-test and post-test design. The population of this study was all of V grade of SDN 10 Poasia consisting of 67 students. Technique of taking sample of this study was purposive sampling involving 21 students. Vocabulary achievement test in the form of multiple choices consisting of 37 numbers was used as instrument of this study. The result showed that there was a significant effect of using nursery rhymes in improving students' English vocabulary achievement. It was proven by the improvement of students' mean score from pretest to post-test. The mean score for pre-test was 34.81 and the mean score for post-test increased to 76.81. It was supported with the result of t-test, the value of Sig. (2tailed) was 0.000 with $a=0.05$. H1 was accepted because the value of Sig. (2-tailed) was below a value. It means that there was a significant effect of using nursery rhymes on students' English vocabulary achievement of the VB students' of SDN 10 Poasia.
\end{abstract}

\section{Introduction}

Teaching vocabulary should be introduced since early age because early age is a golden period where everything can be absorbed easily and quickly. Fajaryani (2015) states that teaching vocabulary should be done to students at the age between 5 and 12 years old because children at those ages are active thinkers and learners.

The success of learning English in early age can be influenced by the ability of a teacher in managing the process of teaching and learning activities which are interesting and fun for children. New ideas in teaching vocabulary such as choose the proper media they need and want are required. Brown (1977) states that media is the tools, material or events 
that establish condition used by a teacher to facilitate the instruction to acquire knowledge, skill, attitudes and engage the learners in a topic or as the basis of a whole activity. A good teacher should understand that teaching vocabulary in elementary school is something new.

SDN 10 Poasia which is located in Kendari, Southeast Sulawesi is an Elementary school that teaches English from grade 3 to grade 6. But, a problem is found to occur in grade 5 where students were bored especially when learning English vocabulary because it was not fun. Students were only asked to memorize. Besides, students' vocabulary ability is low.

Nursery rhyme is one kind of media that can be used in learning. Paradisa (2017) states that nursery rhymes are a song or a simple poem to teach English vocabulary for children. Nursery rhymes use technique of singing as a learning approach because one of the learning techniques for English vocabulary introduction is through singing. Kamtini (in Marlina N, 2016) states that singing is a musical activity which a child can hear through his own senses, voicing the high tone and rhythm of the music in his own voice. For children, singing is a fun activity and also as a tool for them to express their feelings. A good song for children is that lyrics or sentences are not too long so it can be easily remembered and mastered. It most importantly has mission of education. Gordon (Paradisa A, 2017) states that nursery rhymes have short, repetitive and rhythmic lyrics. It helps children easily remember what they have learned. So teaching vocabulary through the nursery rhymes will make it easier for students in elementary school to learn because it is suitable to the learning needs of children.

Based on the reason, researcher is interested in investigating the effect of using nursery rhymes on student's vocabulary achievement.

\section{Research Method}

The researcher used pre-experimental design to conduct this study. A single intact group was tested before and after treatment. The population of this research was all V grade students of SDN 10 Poasia in academic year 2017/2018. The total of population was 67 students. The samples of this study were 21 students. The instrument of this study was vocabulary test which was consisted of 37 items in the form of multiple choices. In analyzing the data, the researcher used dependent or paired sample T-test which used SPSS version 23 on the design of the experiment of the data. A statistical analysis of paired samples t-test (2-tailed test) performed two tests whether or not pretest scores are significantly different from posttest scores.

\section{Result and Data Analysis Pre-test}

Distribution of students' pre-test score in class is described below:

\begin{tabular}{|l|l|l|c|}
\hline Classification & \multicolumn{1}{|c|}{ Value } & Frequency & Percentage \\
\hline Very High & $81-100$ & 0 & $0 \%$ \\
\hline High & $61-80$ & 2 & $16.13 \%$ \\
\hline Average & $41-60$ & 4 & $25.80 \%$ \\
\hline Low & $21-40$ & 11 & $45.16 \%$ \\
\hline
\end{tabular}




\begin{tabular}{|l|l|l|c|}
\hline Very Low & $0-20$ & 4 & $12.91 \%$ \\
\hline \multicolumn{2}{|l|}{ Total $\left(\sum\right)$} & & 21 \\
\hline
\end{tabular}

Based on the results which is shown on the table above, it can be seen that the highest score in experimental class was classified as "Low" criteria with $52.40 \%$ students (11 students), followed by "Very Low and Average" criteria with 19,00\% students (4 students), then "High" criteria with 9,50\% students (2 students) and there was no student $(0.00 \%)$ who got a very high criteria.

\section{Post-test}

Distribution of students' score of post-test is presented in following table:

\begin{tabular}{|l|l|l|c|}
\hline Classification & \multicolumn{1}{|c|}{ Value } & Frequency & Percentage \\
\hline Very High & $81-100$ & 9 & $16.13 \%$ \\
\hline High & $61-80$ & 10 & $48.38 \%$ \\
\hline Average & $41-60$ & 2 & $32.26 \%$ \\
\hline Low & $21-40$ & 0 & $3.23 \%$ \\
\hline Very Low & $0-20$ & 0 & $0 \%$ \\
\hline Total $\left(\sum\right)$ & & & 21 \\
\hline
\end{tabular}

Based on the results that shown on the table above, we can see that the highest score was classified as "High" criteria with $47.60 \%$ students (10 students), followed by "Very High" criteria with $42,90 \%$ students (9 students), then "Average" criteria with $9,50 \%$ students ( 2 students) and there was no student $(0.00 \%)$ who got very low and low criteria.

\section{Normality Test}

\begin{tabular}{|c|c|c|c|c|}
\hline & \multirow{2}{*}{ TEST } & \multicolumn{3}{|c|}{ Kolmogorov-Smirnova } \\
\cline { 3 - 5 } & SOST & .124 & Df & Sig. \\
\hline \multirow{2}{*}{ SCORE } & POtistic & 21 & $.200^{*}$ \\
& PRE & .097 & 21 & $.200^{*}$ \\
\hline
\end{tabular}

Based on the table above, the results of normality test at both of the classes were 0.2 . It means that the data were distributed normally $(0.2>0.05)$.

\section{Hypothesis Testing}

To determine whether there is a significant effect of using Nursery rhymes on students' vocabulary achievement, the researcher used Paired Sample t-test in SPSS 23 application. 


\section{Summary of Hypothesis Testing}

\begin{tabular}{|l|l|l|l|l|}
\hline Df & Sig. & Symbol & A & Result \\
\hline 20 & 0,000 & $<$ & 0,05 & $\mathrm{H}_{1}$ accepted \\
\hline
\end{tabular}

The table above showed that the probability value was less than the level of significance $(0.000<0.05)$. It means that $\mathrm{H}_{1}$ was accepted. Therefore, we can conclude that there was a significant effect of using Nursery rhymes on students' vocabulary achievement at the VB grade students of SDN 10 Poasia.

\section{Effect Size}

The effect size of nursery rhyme was categorized as large effect size (0.96). The result is as follows:

$d=\sqrt{\frac{17,236^{2}}{17,236^{2}+20}} \quad \quad=\mathbf{0 . 9 6}$

\section{Discussion and Conclusion}

This research is aimed at finding out the effect of using nursery rhymes on students' vocabulary achievement. It is clear that there was a significant effect of using nursery rhymes in improving students' vocabulary achievement at the VB grade of SDN 10 Poasia. Paradisa (2017) said that nursery rhymes are songs or simple poems to teach English vocabulary for children. Shwetha (2013) stated that one of main functions of nursery rhymes in language learning is to develop vocabulary. So, one of the solution of teaching vocabulary is applying Nursery rhymes in the learning process where it contains repetition of sounds so students can remember words easily. By mastering nursery rhymes, students can also master vocabulary contained in the nursery rhymes. Nursery rhymes are taught to children with body movements, performed by the instructor, and then they sing songs.

In applying nursery rhmyes, the researcher gave lyrics to help the learning process. Nursery rhymes are often recited by the teacher in the class to the students. When the teacher recited it, she did such various gestures and body movements in order to make the learning fun and easy to be understood by the students.

Besides doing interesting activity, students' vocabulary achievement had significant improvement because nursery rhymes contribute to growth of meaning so it can increase the student's vocabulary. Nursery rhymes contain repetition of sounds and almost all children's song contain words, which are related to their environment so they can remember the words easily. The researcher teaches songs related to the topic. The students seemed to be very enthusiastic to follow the lesson. The researcher can say that using nursery rhymes is a good media in developing students' vocabulary. According to Slattery and Willis (2003), nursery rhymes are very useful for teachers to help children in learning vocabulary since it contained a lot of fun activities which made English learning to be more enjoyable and fun and erased worrying when doing mistakes. Those activities were playing games, singing 
songs, planning one lesson but in various activities, saying rhymes and chants together, and did some dancing movements. Those are united in nursery rhymes.

In applying nursery rhymes, the researcher found some problems. The first, it needs much money and spends time to conduct the treatment and to prepare the equipment. Then to apply nursery rhymes to the classroom takes a lot of time so it is very difficult if it is applied in a short time.

\section{Conclusion}

The effect of using nursery rhymes can be seen from the result of students' vocabulary post-test. The result showed that the score in posttest is better than that of pretest. So, the researcher concludes that there was a significant effect of using nursery rhymes in improving students' vocabulary achievement at SDN 10 Poasia. It is recommended that the teacher must prepare it as better as possible because teaching English vocabulary using nursery rhymes requires long preparation.

\section{References}

Brewster, J. E., Girard (2003). The Primary English Teacher's Guide. London, Penguin English.

Brwon, J. W. L., R. B; Harcleroad, F.F. (1977). Instruction: Technology, Media, and Methods. New York, Mc. Hill Company.

Devina (2013). The Effectiveness of Vocabulary Building Through Nursery Rhymes for Kindergarten Students. English Jakarta, Bina Nusantara University.

Fajaryani, N., Abrar M., Failasofah, Masbirorotni (2015). "Inovasi Pembelajaran Bahasa Inggris di Sekolah Dasar dengan Talular (Teaching and Learning English Using Locally Available Resources)." Jurnal Pengabdian Pada Masyarakat 30(4).

Gerlach, V. S., and Donald, P.E. (1980). Teaching and Learning Vocabulary: Bringing Research to Practice. New Jersey, Lawrence Erlbaum Associates, Inc. .

H, O. (2006). The Use of Nursery Rhymes to Improve Student's Vocabulary Semarang, Semarang State University.

Hornby, A. (2005,). Oxford Advanced Learner's Dictionary. Oxford, Oxford University Press.

Ikra (2016). The Effect of Miming and Picture Technique on student's Vocabulary Achievement at the second Grade students of SMP Negeri 1 Amonggedo. English. Kendari, Universitas Halu Oleo. Bachelor.

Mudawi, G. H. H. (2015). "Using Rhymes and Song for Teaching Core Vocabulary to Elementary School Students." ELT Voices 5. 
Paradisa, A. (2017). "Teaching English Grammar to Young Learners Through Nursery Rhymes Applications. ." English Language and Literature International Conference.

Shwetha, R., M.A., M.Phil. Candidate (2013). "Nursery Rhymes as an Effective Instructional Material for Young Language Learners." 13.

Slaterry, M. a. W., Jane (2003). English for Primary Teachers: A Handbook of Activities and Class Room Language. Oxford, Oxford University Press.

Suyanto, K. (2008). English for Young Learners. Jakarta, Bumi Aksara. 